\title{
REFLECTION
}

\section{The Typewriter Under the Bed: Introducing Digital Humanities through Banned Books and Endangered Knowledge}

\author{
Alexandra Bolintineanu and Jaya Thirugnanasampanthan \\ University of Toronto, CA \\ Corresponding author: Alexandra Bolintineanu (alexandrabolintineanu@gmail.com)
}

In 2017, I taught an Introduction to Digital Humanities course for undergraduate students at the University of Toronto. The course's unifying theme was banned books. What moved me to focus the course in this way was the illegal typewriter that lived under my childhood bed: I grew up in formerly communist Eastern Europe, where typewriters were tightly controlled by the government. Yet my family owned an illegal, unregistered typewriter, hidden under my bed behind the off-season clothes, because they saw the ability to write and disseminate one's thoughts as a technology of survival.

In the Intro to DH course, students explored the intellectual landscape of the digital humanities by thinking about banned books throughout history. They examined early printed books of astronomy; early printed books of the lives of saints; illicitly typewritten and photographed Soviet samizdat; endangered climate change research data rescued by the Internet Archive; and American Library Association data about banned and challenged books for children and young adults. This article reflects on using the lens of banned books and endangered knowledge to focus an Introduction to $\mathrm{DH}$ course and encourage students to interrogate critically how a variety of technologies-from codex to printing press to typewriter to the internet-create, transmit, preserve, and repress knowledge and cultural memory.

Keywords: banned books; censorship; digital humanities; digital pedagogy; introduction to digital humanities; undergraduate learning; rare books

Under my bed, surrounded by off-season clothes, hid a hard black case-metal-clasped, ingrained with dust, wider and much taller than a regular briefcase: inside it, my family's illegal typewriter. I grew up in communist Romania, where means of disseminating information were tightly controlled by the government (Green 1990: 260-61). Newspapers and television were strictly censored, tasked by law with 'devotedly serv[ing] the cause of socialism' (Green 1990: 261, citing the Amended Press Law of 1978). ${ }^{1}$ Books were read by censors, both before publication as well as after (Gogâță 2016). ${ }^{2}$ Films and stage plays were censored before they could run and would sometimes be shut down after a few performances (Constantin Bolintineanu in discussion with the author, February 2017). Yet, there it was: a sleek black Remington-an illegal, unregistered typewriter, tucked under my bed behind bags of snow pants and woolly hats. My grandfather had bought it before the onset of Communism and hidden it in his attic. Decades later, in the 1970s, during a brief relaxation in the political climate, my mother dug it out and took it to university. ('It wasn't as illegal anymore,' she told me recently: 'You could buy typewriter ribbons in the shops.' 'Did you declare it then?' I asked. 'Of course not,'

\footnotetext{
${ }^{1}$ For a focus on television and the public's television-watching habits in the wake of the Amended Press Law, see Paul Campeanu, 'Studies on the mass communication public in Romania,' Cahiers d'études de radio-télévision 30 (1981), 153-58.

2 Gogâță uses a case study of a volume of children's poetry to discuss censorship throughout a book's publication and distribution process. On mechanisms of literary censorship, see also Paul Goma, 'The Rumanian Labyrinth' (Source: Index on Censorship, NO. 6, 1978), in Censorship and Political Communication in Eastern Europe: A Collection of Documents, ed. George Schöpflin (New York: St. Martin's Press, 1983), 165-68.
} 
she said. 'Nobody declared anything' [Danuta Bolintineanu in discussion with the author, February 2017]). By 1983, a new law had come into effect: anybody who wanted to own or keep a typewriter would have to seek and receive police permission and register a type sample of numbers and letters to ensure that any clandestine literature typed with that typewriter could be traced back to its source (Green 1990: 260-61). Our typewriter stayed put under the bed, as unregistered as before. ${ }^{3}$ I remember how hard that typewriter's keys were to push down; how, now and then, they would cross and need untangling; how I could type and type, seeing the ribbon grow more transparent, until the keys struck out colourless indentations onto the page.

Thirty years later, I thought about that typewriter as I designed a second-year undergraduate Introduction to Digital Humanities course focused on banned and endangered books throughout history. The course defined Digital Humanities (DH) broadly, to include computational methodologies applied to traditional humanities research areas but also humanities methodologies applied to the digital. Accordingly, the course's learning goals were twofold: first, to familiarize students with the intellectual landscape of DH, including areas such as digital archives, data curation, text encoding, text analysis, digital mapping, and data visualization; second, to invite students to analyze digital tools and platforms as knowledge production technologies shaped by, and shaping, their own historical contexts. Focusing the course on banned books and endangered knowledge served both these goals. The topic was broad enough to be explored through a variety of tools and methods: distant reading, digital exhibits, data visualization, and mapping. Moreover, it also invited students to interrogate how a variety of texts and technologies help create, transmit, preserve, and repress knowledge and cultural memory-from medieval manuscripts to early printed books, from illicitly typewritten samizdat to endangered digital archives. The very endangerment or censorship of books and archives illuminates technologies of text and the cultural systems of knowledge production and transmission within which these technologies operate.

In the reflection that follows, I will first discuss the rationale for this course focus on banned and endangered books and ground it in DH pedagogy and my local institutional context. Then, focusing on the central unit of our course, digital archives, I will discuss how we studied the intersection of cultural context, technology, and endangered knowledge in four encounters with endangered or banned books and archives: medieval manuscripts; Early Modern banned or censored scientific and theological printed books; Soviet samizdat, transmitted in typewritten transcripts or on photographic film; and endangered research data archives. Third, I will turn to the students' final project, which involved building a multifaceted exhibit about a banned or endangered book, and discuss how the final project contributed to the course learning outcomes. I will conclude by discussing what parts of the course were successful and what parts will change in future iterations of the course.

\section{Background}

Like many DH 101 courses, mine was designed to introduce students to the diverse intellectual landscape of the digital humanities. The curriculum of DH 101 courses has been vigorously discussed for the last decade. In 2010, Lisa Spiro registered a Digital Humanities Education Zotero group. DHers shared over 50 DH and DH-adjacent syllabi in 2010 alone; now, the DH Syllabi folder numbers over 400 submissions (Spiro 2010). In 2013, Johanna Drucker, with David Kim, published Intro to Digital Humanities. This 'online coursebook' presents lesson plans and exercises for a DH 101 course structured around the anatomy of digital projects (Drucker with Kim 2013). The coursebook moves from the fundamental layers of data and text encoding, through ways of analyzing that data (data mining, text analysis, network analysis, GIS analysis), to ways of accessing the data and surfacing insights through interfaces and visualizations. Ryan Cordell (2016) has argued for a different model for teaching $\mathrm{DH}$, one that focuses not on digital humanities itself but on DH-driven insights into disciplines such as literary studies. ${ }^{4}$ Instead of a digital humanities course with digital humanities as its primary topic, Cordell (2016) calls for courses that integrate DH approaches as 'a naturalized part of what literature scholars and historians or other humanists do.' In his case, Cordell

\footnotetext{
${ }^{3}$ For an overview of Romania's censorship laws at this time, see 'Rumania' (sic) in The Encyclopedia of Censorship, 261. For details of effects of these laws and of government policies on day-to day-life in Romania, including on press reporting, see also Bradley Graham, 'Climate of Intimidation Is Evident in Romania,' Washington Post, November 24, 1983. Even more relevant to the control of information, see Carmen Bugan, Burying the Typewriter: A Memoir (Minneapolis, MN: Graywolf Press, 2012), in which she narrates her childhood as the daughter of an imprisoned dissident during Romania's Ceausescu years. The illegal typewriter plays a pivotal role in her father's work as a dissident and in her family's life.

4 See Ryan Cordell, 2016, 'How Not to Teach Digital Humanities,' in Debates in the Digital Humanities, edited by Matthew K. Gold and Lauren F. Klein (Minneapolis: University of Minnesota Press). On his blog, where an earlier version of this essay appears, Cordell notes that he has been developing its central argument since 2012 (http://ryancordell.org/teaching/how-not-to-teach-digitalhumanities, February 1, 2015).
} 
(2016) reconfigured his Intro to DH as Technologies of Text, contextualizing digital humanities concepts and methods within a history of the book:

'Technologies of Text' teaches many DH ideas and skills: in our labs we edit Wikipedia, encode documents in TEI, learn the basics of computational text analysis, or program chatbots using the Python programming language. These labs, however, are framed not within a narrative of recent scholarly revolution, but instead within a sweeping discussion of book and media history. ... Each of these labs helps students understand technology not as something we invented ten years ago (give or take), but as a long continuum of human activity.

Within the history of the book, Cordell argues, students find DH ideas and skills more amenable to critical thought and creative work of their own. More recently, Kristen Mapes (2017) has stated a similar critique even more incisively: 'the lack of disciplinary context common to [Intro to $\mathrm{DH}$ ] classes can lend itself to a showcase of tools rather than a substantive dive into the opportunity that DH provides.' Her answer to this challenge is to focus her introduction to DH course on a specific cultural and literary milieu: the Harlem Renaissance (Mapes 2017).

An informal survey of Introduction to Digital Humanities syllabi reveals a trend towards DH courses that apply DH methodologies to a focused subject area. ${ }^{5}$ In some DH 101 courses, this focused subject area is literary digitality and its analysis. At the University of California, Santa Barbara, Alan Liu's undergraduate courses have brought together literature, digitality, and criticism since $2006 .{ }^{6}$ In a more recent example, Liu's lower-level undergraduate course English 197, Close Reading and Distant Reading in Literary Studies, combines 'the ideas and practices of the original New Critics, the theory and practices of the digital humanities, and the broader debate in literary studies today about the nature of interpretive reading' (Liu 2014; see also Liu 2017). While Liu's courses focus on literary texts, DH 101 courses by Miriam Posner, Lauren F. Klein, and Andrew Goldstone are built around theoretical and technical approaches to data in the humanities (Posner 2015b; Klein 2014; Goldstone 2014). ${ }^{7}$ In other courses, such as Ryan Cordell's and Whitney Trettien's, digital media and digital literary studies are framed within the study of book history and reading more broadly (Cordell 2014; Trettien 2017). Most often, the focus of introductory courses is on a special topic-usually a cultural moment, an author, a historical period or milieu. Joanna Swafford (2016) introduces DH through Arthur Conan Doyle's Sherlock Holmes stories. Brian Croxall (2017) introduces DH through twentieth- and twenty-first-century literature in English. Kristen Mapes (2017) introduces DH by focusing on the Harlem Renaissance. Moacir P. de Sá Pereira (2017a, 2017b) uses DH methods to reflect on literary spaces and geographies of New York. In the Humanities Commons' CORE repository, DH syllabi whose topic is 'digital humanities qua digital humanities' are graduate courses that do not limit themselves to an uncritical showcase of tools and methods; instead, they invite students to consider DH's disciplinary metanarrative, its self-construction as an academic domain. For example, Shawn Graham's Carleton University graduate seminar, Introduction to Digital Humanities, explicitly begins with the question 'What should undergrads know about DH?' and builds the course around collaboratively authoring an open textbook answering that question (Graham 2017).

My own approach was a hybrid of the book history and special topic approaches. I focused the course on banned books and endangered knowledge because it is a topic that can illustrate diverse DH approaches, that appeals to students from a variety of disciplines, and that contains the seeds of critical reflection on knowledge production and transmission. It also allows me to draw on my research as a medievalist and my lived experience growing up in communist Romania. There are additional advantages to this topic. At the University of Toronto, banned books is an area of strength in terms of research, librarianship, and rare book collections. At the Centre for Comparative Literature, Ann Komaromi studies samizdat, uncensored writing in the former Soviet Union. Komaromi's digital humanities Project for the Study of Dissidence and

${ }^{5}$ This informal survey draws on DH pedagogy scholarship cited below-Cordell 2014, Swafford 2016, Croxall 2017, Mapes 2017, and Selisker 2016-as well as on syllabi published online, including, but not limited to, the collection of 53 syllabi deposited under the subject 'Digital Humanities' in Humanities Commons' CORE repository (https://hcommons.org/deposits/?facets[subject_facet] []=Digital+humanities\&facets[genre_facet][]=Syllabus, accessed May 30, 2018).

6 See Alan Liu, 2006, 'English 194, "Creativity \& Collaboration: A Project on New Modes of Authorship"' (Spring). http://liu.english. ucsb.edu/english-194-creativity-collaboration-a-project-on-new-modes-of-authorship-spring-2006/).

7 Klein's syllabus is no longer available online. Goldstone's and Klein's syllabi are briefly analyzed in Scott Selisker, 2016, 'Digital Humanities Knowledge: Reflections on the Introductory Graduate Syllabus,' in Debates in the Digital Humanities, edited by Matthew K. Gold and Lauren F. Klein (Minneapolis: University of Minnesota Press), http://dhdebates.gc.cuny.edu/debates/2, accessed May 30, 2018. 
Samizdat is an electronic archive featuring uncensored journals, timelines of dissident movements, and interviews with activists from the Soviet Union, 1956-1986' (Komaromi 2011). P. J. Carefoote, Head of the Department of Rare Books and Special Collections at the University of Toronto's Thomas Fisher Rare Book Library, has written on censorship (2007) and curated two exhibits on banned books and forbidden knowledge $(2005,2017)$. By a stroke of good luck, the latter exhibit ran during the period of my course (September-December 2017). Carefoote's collaboration, and that of the library more broadly, were crucial to the success of the course: in hands-on sessions, students learned how to handle rare books and learned by close inspection what dangers-from bookworms to the censor's blotting brush and the public hangman's fire-these books have survived.

Furthermore, I wanted to position digital humanities research so as to enable students, in Swafford's words, to 'historiciz[e] their own technological moment' (Swafford 2016: 371-72). To this end, I focused on banned books and endangered knowledge because censorship and danger to knowledge disrupt and transform social, cultural, and technological systems of knowledge production and transmission, and in so doing render these systems more visible. The course explored the interaction of technology, social and cultural context, and banned or endangered knowledge through four encounters with endangered or banned books and archives: medieval manuscripts; Early Modern scientific and theological printed books; Soviet samizdat, transmitted in typewritten transcripts or on photographic film; and endangered research data archives.

The first encounter-from my own field of specialization, Old English literature-is a riddle from the tenthcentury manuscript of the Exeter Book. A poem about book damage surviving in a damaged manuscript, the riddle opens up discussion about medieval text technologies (from oral poetry to manuscripts), their vulnerabilities, and their study through digital manuscript archives.

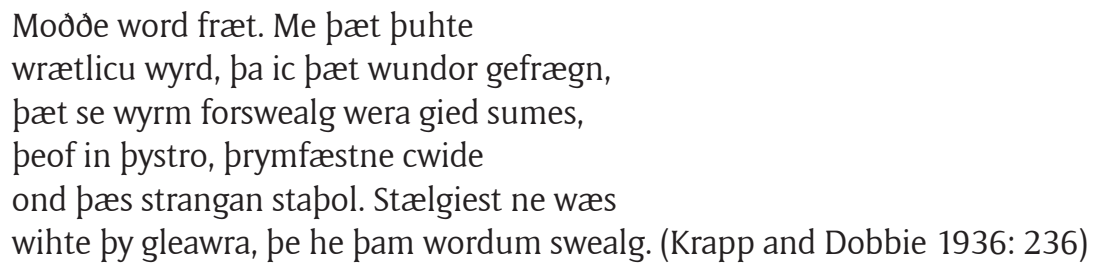

A moth devoured words. That seemed to me a marvellous fate, when I heard that wonder, that the worm, thief in the darkness, swallowed a certain man's song, a glory-fast speech and its strong foundation. The stealing guest was not one bit the wiser for those words he swallowed. (My translation)

Students guess the solution 'bookworm' (insect) easily. I reward them with suitably disgusting photographs of the insects and the holes they leave in books. But then we return to the riddle: Is the bookworm answer perhaps too easy?

We take a closer look at the riddle to find out. What exactly is it that the worm devours? It eats words, a man's song, a speech and its foundation. The foundation could be the physical container, the manuscript page itself. But in Old English, poetry may be written or spoken. Old English poetry survives in manuscripts, but it is 'deeply influenced by its situation in a residually oral culture' (O'Brien O'Keeffe 1994: 148), a culture where poetry may have been written down but still would have been heard rather than read by most people. When such poems were composed, their poets drew on stock phrases, images, and episodes; when such poems were recited, their listeners or readers recognized these traditional phrases and reacted to the phrases' cargo of traditional affective associations. ${ }^{8}$ I argue, along with Nicolas Jacobs, Martin Foys, and

\footnotetext{
${ }^{8}$ See Katherine O'Brien O'Keeffe, 1994, 'Editing and the Material Text,' in The Editing of Old English: Papers from the 1990 Manchester Conference, edited by D.G. Scragg and Paul E. Szarmach (Cambridge: D. S. Brewer), 147-154 (supra n. 24); Alain Renoir, 1988, A Key to Old Poems: The Oral-Formulaic Approach to the Interpretation of West-Germanic Verse (University Park: Pennsylvania State University Press), 86.; John Miles Foley, 2003, 'How Genres Leak in Traditional Verse,' in Unlocking the Wordhord: Anglo-Saxon Studies in Memory of Edward B. Irving, Jr., edited by Mark C. Amodio and Katherine O'Brien O'Keeffe (Toronto: University of Toronto Press), 76-108; John Miles Foley, 1991, Immanent Art: From Structure to Meaning in Traditional Oral Epic (Bloomington: Indiana University Press); Mark C. Amodio, 2004, Writing the Oral Tradition: Oral Poetics and Literate Culture in Medieval England (Notre Dame: University of Notre Dame Press).
} 
Megan Cavell, that the bookworm riddle's answer is at least twofold. ${ }^{9}$ One of the archives at risk is written and material: books, the foundation of human knowledge, are at risk from the insects that devour their pages. The other archive is oral and memorial: the vocabulary of traditional poetry, words and images and their deep-rooted affective resonances. ${ }^{10}$ If this shared poetic treasury, this collective memory, is the strong foundation' for speech and song, then what is the heedless worm that devours it? Forgetfulness? History? Time? The discussion of our riddle serves to focus students' attention on technologies of text and on the way that complementary technologies of text-here, oral poetry and manuscript production-coexist and interact. The riddle also evokes two kinds of at-risk archives: archives endangered because their physical form is endangered and archives endangered because, for reasons technical or cultural, they become illegible, inaccessible to changing reader communities.

After considering medieval manuscripts and their readers (and, as it were, consumers), students met medieval manuscripts and early books in person. The class visited the Thomas Fisher Rare Book Library, where Carefoote guided the students through the current exhibit, Flickering of the Flame: The Book and the Reformation. The exhibit examined 'the importance of the printing press to the Reformation movement,' thus highlighting the two aspects of the course: technology and banned books (Carefoote 2017). Carefoote invited students to handle and examine endangered or forbidden books more closely. In the library's reading room, we looked at medieval manuscripts with bookworm marks. Then we examined early printed books of the works of Galileo and Copernicus, as well as the Catholic Church's Index Librorum Prohibitorum (List of Prohibited Books), in which these works appeared. We photographed a copy of the famous Wicked Bible, in which the commandment 'Thou shalt not commit adultery' was transformed into 'Thou shalt commit adultery,' turning the bibles into highly blasphemous materials that were subsequently swiftly and heavily censored (Carefoote 2007).

The lens of censorship highlights the mechanisms of knowledge transmission. For example, many works of Protestant theology were banned in sixteenth-century Catholic Europe. But the relatively new (to Europe) technology of the printing press was indispensable to the Protestant Reformation and the rapid spread of its theological ideas. Technology fed theology; theology fed technology. Just as the printing press helped Protestantism flourish, so Protestantism helped printing flourish. Under the leadership of Protestant Reformer John Calvin, printing became the major industry in Geneva: the city's printers produced theological literature for Protestant readers throughout Europe, and especially France, where such materials were strictly banned. The books themselves testify to Geneva's identification with Protestant literature: because Geneva had become so strongly associated with Protestantism, books printed in the city were banned in Catholic Europe, so Genevese printers frequently omitted the place of printing to allow their censored books to be more easily imported into Catholic countries (Carefoote 2007: 31-38). Carefoote showed the students one book that displayed the place of printing and several that did not. In course-end evaluations, more than one student expressed enthusiasm about the trip, one even noting that 'the trip to the rare book library was definitely the highlight of [their] entire semester' (anonymized student evaluations).

The next encounter with banned books was through a major digital humanities project, self-described as 'an electronic archive' of unauthorized literature in the former Soviet Union: Ann Komaromi's aforementioned Project for the Study of Dissidence and Samizdat (2015). Komaromi focuses on the creation and circulation of samizdat, literature self-published outside of authorized channels and without prior approval of official censors. In the Soviet Union, this form of literature was unauthorized, and therefore dangerous for writers, copyists, and readers, who could face prison for producing or consuming it (Komaromi 2017). Samizdat, Komaromi points out, was not printed: instead, it was copied by hand, on photographic film, or, most often, on typewriters (often unregistered, illicit typewriters, like the one discussed earlier in the paper and in the course). The material was then distributed from friend to trusted friend. These unofficial distribution networks meant that the textual forms of samizdat were flexible and unstable: the roles of writers, editors, and readers overlapped, because copyists-readers as well as unofficial publishers-would intervene in the text by abbreviating, annotating, or even substantially adapting the texts they were transmitting. The forms

\footnotetext{
${ }^{9}$ Nicholas Jacobs, 'The Old English 'Book-moth' Riddle Reconsidered,' Notes and Queries 35, no. 3 (1988): 290-92; Martin Foys, 'The Undoing of Exeter Book Riddle 47: "Bookmoth,"' in Transitional States: Cultural Change, Tradition and Memory in Medieval England, A Festschrift for Allen Frantzen, edited by Graham Caie and Michael D. C. Drout (Tempe: Arizona Center for Medieval and Renaissance Studies, forthcoming). Pre-publication draft available online: https://doi.org/10.17613/M6RP7H, accessed February 21, 2018. See also Megan Cavell, 'Riddle 47,' 2015, accessed February 21, 2018, https://theriddleages.wordpress.com/2015/11/23/ commentary-for-riddle-47/ (Cavell 2015).

${ }^{10}$ Jacobs (1998) and Foys argue that what is devoured is (respectively) earthly fame, human knowledge, and 'learning, or more precisely the extra-ordinary struggle to learn' (Foys 2017: 2).
} 
of texts were powerfully shaped by the technologies of transmission, including handwriting, typewriting, or photography (Komaromi 2017). In its textual fluidity, Komaromi (2017) notes, samizdat literature recalls not the relative textual stability of print culture, but the changefulness of medieval manuscript texts: instead of one stable text widely distributed, samizdat and manuscript texts alike live in relatively few copies and are relatively polymorphous. ${ }^{11}$ They also resemble, in Jerome McGann's evocative phrase, the equally polymorphous 'radiant textuality' of the digital (McGann 2001).

From this particular digital archive of samizdat we turned to digital archives more broadly, and to the risks that digital archives must contend with. Like the 'strong foundation' of knowledge devoured by the bookworm and the two archives, material and memorial, that the riddle evokes, digital archives live between two modes, the physical and the digital: they are abstracted versions of physical objects, residing in the collective memory of server farms. We examined how rare books are digitized: their bodies shipped to data centres in protective boxes like vampire coffins, their spines supported by book cradles, their pages meticulously photographed at high resolution, their content captured in what Miriam Posner calls 'computationally tractable' ways by metadata, their digital surrogates preserved in library platforms (Posner 2015a). 'How long will data last once it has been digitized?' I asked the students. Quite a few students across disciplines, struck by the fragility of rare books and the elaborate care their bodies require, said forever, imagining the digital as disembodied, invulnerable to bookworms and time. As Nowviskie (2016) notes, however, '[d]igital libraries are so inescapably material that they hurt.' As with bookworms, the vulnerabilities of digital archives include specific computing risks, from bit rot to obsolescent software, but also broader risks-far harder to counteract-including disasters, climate change, ${ }^{12}$ and relentless time itself. ${ }^{13}$ Nor does the distributed storage of the 'cloud' obviate the risks: despite the metaphor's celestial overtones, the 'cloud' is all too earthbound, its data susceptible to destruction, decay, or geopolitics (Burrington 2015).

My students and I examined the University of Toronto's policies around the ethical and technical management of human research data ${ }^{14}$ and discussed how DH projects-and data-driven projects more broadly-must be mindful of risks brought about by storage infrastructures. Even when such data is not banned, it may well be endangered within the technical, institutional, and cultural systems in which it lives. We discussed the 1986 BBC Domesday Book project and its data preservation challenges. ${ }^{15}$ Having examined medieval manuscripts conceptually and in person, students were particularly struck by the resilience of the 1085 Domesday Book manuscript compared to the fragility of the complex 1986 Doomsday Book multimedia project. When we brainstormed data loss scenarios with respect to digital humanities projects, students' responses were highly reflective of their individual disciplines. History majors talked about the difficulty of accessing objects and documents that have not been digitized. Political science majors pointed out how global inequities bias digitization and the preservation of cultural heritage. Bioethics majors brought up medical research data and its profound privacy concerns. Computer science majors talked about obsolescent hardware, discussed best practices for writing sustainable code, or recounted the horrors of having to debug and develop someone else's poorly documented code. And everyone had a horror story of lost or mistakenly deleted data (data lost to the teeth of a cat was my personal favourite this year). ${ }^{16}$

We also discussed ways in which digital archives are vulnerable to politically motivated suppression, including data deleted outright, data no longer accessible to the public, or data subject to what Nowviskie (2017) calls the 'library problems of misrepresentation, thwarted agency, and structural neglect,' housed in archives whose controlled vocabularies are pejorative or marginalizing or in archives of marginalized cultures that were collected via appropriation or not collected at all. These archives represent knowledge that, though it may not be explicitly censored, is nevertheless endangered. Nowviskie, Marisa Elena Duarte,

\footnotetext{
${ }^{11}$ For medieval manuscripts' variant textuality, see Paul Zumthor, 1972, Essai de poétique médiévale, Collection Poétique (Paris: Éditions du Seuil); and Bernard Cerquiglini, 1989, Éloge de la variante (Paris: Éditions du Cerf), translated by Betsy Wing, 1999, as In Praise of the Variant: A Critical History of Philology (Baltimore: Johns Hopkins University Press).

12 See Eira Tansey, 2017, 'When the Unbearable Becomes Inevitable: Archives and Climate Change,' May 16, 2017, http://eiratansey. com/2017/05/16/fierce-urgencies-2017/.

${ }^{13}$ See Bethany Nowviskie, 2015, 'Digital Humanities in the Anthropocene,' DH2014 Keynote Lecture, accessed February 21, 2018, http://nowviskie.org/2014/anthropocene/.

${ }^{14}$ The University of Toronto's research data management policies include guidelines on handling sensitive data (including de-identification, i.e., anonymizing data) and on Canadian funders' data publication requirements (two of the three federal funding bodies mandate that data created with government funding be made public) (University of Toronto Libraries 2018).

${ }^{15}$ For a discussion of the two Domesday Books in the context of data's fragility, see Daniel J. Cohen and Roy Rosenzweig, 2006, 'Preserving Digital History' (chapter), in Digital History: A Guide to Gathering, Preserving, and Presenting the Past on the Web (Philadelphia: University of Pennsylvania Press), http://chnm.gmu.edu/digitalhistory/preserving/1.php, accessed May 30, 2018.

${ }^{16}$ Thanks to Kunal Sharma for sharing this particular gem and for permission to publish it.
} 
and Miranda Belarde-Lewis, among others, discuss anti-racist or anti-colonial libraries and archives in a US context (Nowviskie 2017; Duarte and Belarde-Lewis 2015). In our Canadian classroom, students brought up the Truth and Reconciliation Commission (TRC), dedicated to telling and documenting Canada's Indian residential school system. The TRC's findings include a record of survivors' reports of a colonial school system that separated Indigenous children from their families and communities, forced Indigenous children (often through horrific physical and psychological abuse) to adopt settler cultural and religious norms, and deliberately aimed at the erasure of Indigenous cultures and spiritual practices (Truth and Reconciliation Commission 2015). The digital archives of the National Centre for Truth and Reconciliation document the history of residential schools in Canada. They do not restore the searing losses and injustices of the past and the present. They can, however, function as 'a place of learning and dialogue where the truths of their [the survivors'] experiences are honoured and kept safe for future generations,' with the hope that 'their families, communities and all of Canada would learn from these hard lessons so they would not be repeated,' and where they can share 'the wisdom of the Elders and Traditional Knowledge Keepers on how to create just and peaceful relationships amongst diverse peoples' (National Centre for Truth and Reconciliation). An archive that documents profound harm to Indigenous people-including the banning and endangerment of cultural knowledge-becomes cultural memory in its own right, 'a legacy gift to all Canada' (National Centre for Truth and Reconciliation).

Having considered digital archives of (and as) endangered knowledge, the students turned to their final project in this class: a digital exhibit about a banned, challenged, or endangered book. Students had the option to draw from the Fisher Library's collection or from the American Library Association's Banned Books lists (American Library Association 2013) and then explore the book through the following three pieces: a digital collection; an exhibit; and either a data visualization or a video game. All of their projects were then integrated into one Omeka site. ${ }^{17}$ The digital exhibit described the book, both as a literary text and as a physical object. It analyzed the social and historical context in which the book was written, challenged, or banned, and analyzed the role of technologies of text in the book's banning or transmission. The digital collection catalogued evidence about the book, including photographs of the book itself (title page, illustrations, marginal annotations, damage, and other interesting features), taken by the student; digitized newspaper articles; images of related objects from cultural heritage repositories; and other relevant multimedia. Each object of the digital collection had to be described using Dublin Core metadata. Students photographed rare books at the Fisher Library, collected news articles about book burnings (of The Satanic Verses and the Harry Potter books, for example), and juxtaposed passages from Margaret Atwood's The Handmaid's Tale-challenged and censored in Canada when first published-with recent photographs of Handmaid's Tale-costumed protesters for reproductive justice in the United States.

As an addition to the Omeka site, students were also asked to create a game using Twine, or a data visualization using Palladio, Cytoscape, Voyant, or Neatline, to present an aspect of their banned book. The goal of this component was for students to remediate an aspect of their material-in Twine, exploring their banned book through interactive storytelling; in Palladio, Cytoscape, and Voyant, through quantitative data visualization; and in Neatline, through map- and timeline-based storytelling. The assignment also invited students to reflect on the product of their remediation exercise and discuss how their platform of choice illuminated or distorted their material. In preparation for this component of the project, we discussed the theoretical work of Drucker (2011), Nowviskie (2014), and Posner (2015a) pertaining to humanities data visualization. Then we experimented with tools that privilege quantitative data, such as Voyant and Palladio, and tools that privilege perspectival, storytelling approaches, such as Neatline. Data visualizations included Neatline timelines of publication and banning; annotated transcriptions of important pages of the book; Palladio or Cytoscape network graphs of characters interacting in a specific chapter of the book, illustrating through their interactions why that book might have been challenged or banned; and Neatline maps of bans or challenges, based on American Library Association data. Some students chose instead to build a brief interactive Twine game to explore an aspect of the banned book. Games ranged from a dive into the world of Fahrenheit 451 and an exploration of Galileo Galilei's social network, to scenarios of time travel to seventeenth-century London, and to a dystopian surveillance-state setting in which The Communist

\footnotetext{
17 On teaching with Omeka, see Jeffrey McClurken, 2011, 'Teaching and Learning with Omeka: Discomfort, Play, and Creating Public, Online, Digital Collections,' in Learning Through Digital Media Experiments in Technology and Pedagogy, edited by R. Trebor Scholz (New York: The Institute for Distributed Creativity), 137-49. See also Stephanie A. Schlitz and Garrick S. Bodine, 2012, 'The Martha Berry Digital Archive Project: A Case Study in Experimental pEDagogy,' Code4Lib 17, June 1, 2012, http://journal.code4lib.org/ articles/6823.
} 
Manifesto circulates among oppressed factory workers. Each of the games took a speculative or remediating view of the book, inviting readers/players into the book's historical or fictional world or turning the book's ideological premises into playable dystopias in order to highlight these premises' stakes. With only one exception, all the main characters whom the students invited me to play died multiple horrible deaths.

One student, Jaya Thirugnanasampanthan, who is co-author of this paper (she contributes the exhibit video), was especially resourceful in sourcing items for her collection. She used an Open Records Act request to acquire a school district's email correspondence regarding the withdrawal of Jay Asher's young adult novel Thirteen Reasons Why from that district's school libraries and to explore how the book's banning worked across multiple technological platforms. ${ }^{18}$ Thirugnanasampanthan decided to work on Thirteen Reasons Why because she noticed that challenges to the book were connected to its life across different media. Specifically, Thirugnanasampanthan noted that controversy around Thirteen Reasons Why broke out not when the book was first published in 2007, but years later when the book moved to a new medium with the release of the Netflix series 13 Reasons Why in March 2017 (American Library Association 2013). Thirugnanasampanthan wanted to investigate how this multiple-media presentation of the book influenced its banning.

After scrutinizing data from the American Library Association's Most Challenged Books lists, Thirugnanasampanthan turned to one specific school library in Colorado where a challenge to the book originated: Mesa County Valley School District 51, Colorado. ${ }^{19}$ She traced the story through local news. Then she used a CORA (Colorado Open Records Act) request to access the entire school board correspondence about banning the book from the school's library system-not the paper book, but the book in its electronic form. The challenge originated with an administrator. The project revealed how the administrator communicated with stakeholders within the school board to ask that the book be removed from public school digital libraries, how the librarians pushed back against the initiative, and how the administrator, convinced by librarians' arguments, backed away from the ban. In addition to building an Omeka collection based on the CORA documents, Thirugnanasampanthan visualized the development of the story through a Neatline Timeline that tells a well-documented, complex story about a challenge to a book unfolding in its local, institutional, and technological context. In May 2018, Thirugnanasampanthan's project was recognized for research excellence and 'effective and innovative use of information sources' with a University of Toronto Libraries Undergraduate Research Prize (University of Toronto Library 2018).

While few students' projects were as inventive and as rigorous as Thirugnanasampanthan's, all of the projects demonstrated the students' ability to read texts closely, to engage with the physical particulars of the books (from bookworm damage to passages deleted by censors), to think critically about the books and their bans against the background of wider social phenomena, to research and carefully document a collection of artifacts, and to think about the afterlives of books in print, in the press, across internet cultures, and within the intellectual landscape of DH. The projects demonstrated, too, the students' proficiency with technical tools, from content management systems like Omeka to data visualization tools like Neatline, Palladio, Cytoscape, and Voyant. Most interesting to me was the different range of perspectives that emerged as students examined their books in different digital modes. The exhibits were analytical, historicized reflections that focused on the banned or endangered books' persistent or even increased circulation in the face of censorship. In other words, the exhibits told stories of the books' survival. By contrast, the students' games focused on people for whom engagement with banned books led to death or disaster. The games counted this engagement's human cost. Using multiple digital tools, the students' projects reflected the multivoiced and methodologically heterogeneous field of $\mathrm{DH}$, to which this course provided only a brief introduction. They also reflected the course-long encounter with endangered or banned knowledge as represented by medieval manuscripts, early printed books, samizdat, and digital research data.

\section{Conclusions}

While censorship proved to be a very useful lens through which to approach the study of digital humanities, and while the course generated impressive student work, there were two major problems that I hope to remedy in future offerings. Chief among them was the students' lack of familiarity with scholarly research practices. While excavating the historical context of endangered or banned books, a substantial portion of

\footnotetext{
${ }^{18}$ See Appendix 2 of this article, 'Thirteen Reasons Why.' Script and exhibit by Jaya Thirugnanasampanthan; with thanks to Isabelle Zhu for the voiceover. Content note: brief image of fictional self-harm or suicide in the first 1.5 minutes of the video.

19 See CBS/APA, 2017, “'Thirteen Reasons Why” briefly pulled by Colorado school district,' CBS News, May 16, 2017, accessed May 30, 2018, https://www.cbsnews.com/news/thirteen-reasons-why-colorado-school-district/.
} 
the class initially drew on non-scholarly digital publications, such as blog posts and popular press articles, for their research. The scaffolding of the project allowed me to steer students towards solid scholarship based on their rough drafts. But in future iterations of the course, I will provide more extensive practice with such research ahead of time by incorporating a library research mini-workshop, adopting Miriam Posner's 'shelfie' assignment (Posner 2017), or inviting students to produce an annotated bibliography in which they document not only their sources, but also their own research process.

The second change I would make is not prompted by student work, but by my own reflection on the course's shape: I want to make the concept of 'technologies of text,' situated within a framework of media studies theory, a more explicit backbone of the course, through two changes. First, our encounters with text technologies this year were not in chronological order as narrated above because of guest speakers' time constraints; in following iterations, they will be in chronological order, providing a clearer historical narrative. Second, I will align our hands-on experience with technologies of text with theoretical reading. Before our visit to the Rare Books Library, I will assign Alan Liu's 'Imagining the New Media Encounter' as class reading. Liu gracefully introduces the field of digital literary studies by reflecting on the 'new media encounter,' on historical narratives of transformative interaction between different technologies of text (Liu 2007). This perspective will more firmly connect the modules of the course, positioning the digital as one text technology in a long historical continuum. After our visit to the Rare Books Library, I will introduce students explicitly to the concept of remediation ${ }^{20}$ and discuss how the final project of the class is designed to reflect on the interaction between modes of knowledge production, technologies of text, and the historical contexts in which knowledge and technologies operate.

An aspect of the course that I will not change-an aspect that was successful beyond my expectations-is the visit to the Thomas Fisher Rare Book Library and the associated assignment in which students chose one particular banned or endangered book and reflected on this book through digital exhibits, data visualizations, and games. The visit and assignment invite students to engage with the intellectual content as well as the materiality of these books, their historical and technological context, and their possible digital afterlives. The rare books testify to vulnerability and resilience alike. They bear deliberate physical damagethe censor's knife or blotting ink-or they are, like the Wicked Bible, rare survivors of a sustained programme of censorship. For now, however, here they are. We touch and turn the pages. We strike the typewriter's keys. If the ribbon is not too faded, words appear.

\section{Additional Files}

The additional files for this article can be found as follows:

- Introduction to Digital Humanities: WDW235H1F1. Introduction to Digital Humanities course syllabus (undergraduate; focus: banned books) and final project handout (exhibit on a chosen banned book). DOI: https://doi.org/10.5334/kula.30.s1

- Exploring the Censorship of Jay Asher's Thirteen Reasons Why. Video overview of Jaya Thirugnanasampanthan's final project, a Neatline exhibit focusing on the attempted censorship of Jay Asher's Thirteen Reasons Why in Mesa County Valley School District 51, Colorado. Script and exhibit by Jaya Thirugnanasampanthan; with thanks to Isabelle Zhu for the voiceover. Content note: brief image of fictional self-harm or suicide in the first 1.5 minutes of the video. DOI: https:// doi.org/10.5334/kula.30.s2

\section{Acknowledgements}

Thanks and acknowledgements to the anonymous reviewers, whose observations and critiques made this a far stronger paper, and to Jacquelyn Clements, for critical proofreading; all errors, of course, remain the authors' own. Thanks to Prof. Ann Komaromi for her riveting lecture on samizdat, and to Dr. P. J. Carefoote for inviting us to the book room and giving us the gift of his time and expertise. To Constantin and Danuta Bolintineanu: regular-sized thanks for participating in the interview, and immense thanks, always, for books, love, and courage.

\section{Competing Interests}

The authors have no competing interests to declare.

\footnotetext{
${ }^{20}$ See J. David Bolter and Richard A. Grusin, 1999, Remediation: Understanding New Media, (Cambridge, Mass: MIT Press).
} 


\section{References}

American Library Association. 2013. "Top Ten Most Challenged Books Lists." Accessed May 30, 2018. http:// www.ala.org/advocacy/bbooks/frequentlychallengedbooks/top10. Archived at: https://perma.cc/T4R56ETD.

Amodio, Mark C. 2004. Writing the Oral Tradition: Oral Poetics and Literate Culture in Medieval England. Notre Dame, IN: University of Notre Dame Press.

Bolter, Jay David, and Richard A. Grusin. 1999. Remediation: Understanding New Media. Cambridge, MA: MIT Press.

Burrington, Ingrid. 2015. "The Strange Geopolitics of the International Cloud." Atlantic, November 17, 2015. https://www.theatlantic.com/technology/archive/2015/11/the-strange-geopolitics-of-theinternational-cloud/416370/. Archived at: https://perma.cc/E5SR-HFPK Accessed May 30, 2018.

Câmpeanu, Pavel. 1981. "Studies on the Mass Communication Public in Romania." Cahiers d'études de radiotélévision, 30: 153-58.

Carefoote, Pearce J. 2005. Nihil Obstat: An Exhibition of Banned, Censored and Challenged Books in the West, 1491-2000: Exhibition and Catalogue. Toronto: Thomas Fisher Rare Book Library.

Carefoote, Pearce J. 2007. Forbidden Fruit: Banned, Censored, and Challenged Books from Dante to Harry Potter. Toronto: Lester, Mason \& Begg.

Carefoote, Pearce J. 2017. "Flickering of the Flame: The Book and the Reformation." Exhibition. September 25, 2017 to December 25, 2017. Thomas Fisher Rare Book Library. https://fisher.library.utoronto.ca/ exhibition/3811.

Cavell, Megan. 2015. "Riddle 47." The Riddle Ages, November 23, 2015. Accessed February 21, 2018. https:// theriddleages.wordpress.com/2015/11/23/commentary-for-riddle-47/. Archived at: https://perma.cc/ TN95-UZCE.

CBS/APA. 2017. "'Thirteen Reasons Why' Briefly Pulled By Colorado School District." CBS News, May 16, 2017. Accessed May 30, 2018. https://www.cbsnews.com/news/thirteen-reasons-why-colorado-schooldistrict/. Archived at: https://perma.cc/7PQX-6HA3.

Cerquiglini, Bernard. 1999. In Praise of the Variant: A Critical History of Philology [Éloge de la variante. Histoire critique de la philologie]. Translated by Betsy Wing. Baltimore: Johns Hopkins University Press.

Cohen, Daniel J., and Roy Rosenzweig. 2006. "The Fragility of Digital Materials." Digital History: A Guide to Gathering, Preserving, and Presenting the Past on the Web. Philadelphia: University of Pennsylvania Press. http://chnm.gmu.edu/digitalhistory/index.php Accessed May 30, 2018.

Cordell, Ryan. 2014. "Technologies of Text." Syllabus. http://f14tot.ryancordell.org/. Archived at: https:// perma.cc/92R6-K4WM.

Cordell, Ryan. 2016. "How Not to Teach Digital Humanities." In: Debates in the Digital Humanities, Matthew K. Gold, and Lauren F. Klein (eds.). Minneapolis: University of Minnesota Press. http://dhdebates.gc.cuny. edu/debates/text/87. Archived at: https://perma.cc/NRZ6-8CB5.

Croxall, Brian. 2017. “Screwing Up DH101: My Talk at MLA 2017." http://www.briancroxall.net/2017/01/23/ screwing-up-dh101-talk-at-mla-2017/. Archived at: https://perma.cc/LX4U-QY2M. Syllabus: http:// www.briancroxall.net/s14dh/s14dh.pdf.

De Sá Pereira, Moacir P. 2017a. "Digital Literary Studies: Novel Maps of New York." Syllabus. Accessed May 30, 2018. DOI: https://doi.org/10.17613/M6D56V

De Sá Pereira, Moacir P. 2017b. "Media History of New York." Syllabus. Accessed May 30, 2018. DOI: https:// doi.org/10.17613/M6HV72

Drucker, Johanna. 2011. "Humanities Approaches to Graphical Display." Digital Humanities Quarterly, 5(1). http://www.digitalhumanities.org/dhq/vol/5/1/000091/000091.html. Archived at: https://perma.cc/ F8MK-DVEL.

Drucker, Johanna, with David Kim. 2013. "Intro to Digital Humanities: Concepts, Methods, and Tutorials for Students and Instructors." DH101. Accessed February 21, 2018. http://dh101.humanities.ucla.edu. Archived at: https://perma.cc/P9PY-LLCE.

Duarte, Marisa Elena, and Miranda Belarde-Lewis. 2015. "Imagining: Creating Spaces for Indigenous Ontologies." Cataloging \& Classification Quarterly, 53(5-6): 677-702. DOI: https://doi.org/10.1080/0 1639374.2015.1018396

Foley, John Miles. 1991. Immanent Art: From Structure to Meaning in Traditional Oral Epic. Bloomington: Indiana University Press.

Foley, John Miles. 2003. "How Genres Leak in Traditional Verse." Unlocking the Wordhord: Anglo-Saxon Studies in Memory of Edward B. Irving, Jr., Mark C. Amodio, and Katherine O'Brien O'Keeffe (eds.), 76-108. Toronto: University of Toronto Press. DOI: https://doi.org/10.3138/9781442682931-007 
Foys, Martin. 2018. "The Undoing of Exeter Book Riddle 47: 'Bookmoth." Transitional States: Cultural Change, Tradition and Memory in Medieval England, Graham Caie, and Michael D. C. Drout (eds.). Tempe: Arizona Center for Medieval and Renaissance Studies (ACMRS).

Gogâță, Christina. 2016. "Parallel Libraries of the Former Securitate. Ana Blandiana, 'Întâmplări de pe strada mea." Studia Universitatis Babes-Bolyai-Philologia, 61(2): 97-100.

Goldstone, Andrew. 2014. "Literary Data: Some Approaches." Syllabus. Accessed May 30, 2018. http://www. rci.rutgers.edu/ ag978/litdata/syllabus/. Archived at: https://perma.cc/MR9S-2UPL.

Goma, Paul. 1983. "The Rumanian [sic] Labyrinth." Censorship and Political Communication in Eastern Europe: A Collection of Documents, George Schöpflin (ed.), 165-68. New York: St. Martin's Press.

Graham, Bradley. 1983. "Climate of Intimidation Is Evident in Romania." Washington Post, November 24, 1983. https://www.washingtonpost.com/archive/politics/1983/11/24/climate-of-intimidation-isevident-in-romania/360b20f4-2dfd-4c00-9317-76548c1f0319/?utm_term=.16013ccf9a68 Accessed May 30, 2018. Archived at: https://perma.cc/U6QT-XRBC.

Graham, Shawn. 2017. “Introduction to Digital Humanities.” Syllabus. Accessed May 30, 2018. DOI: https:// doi.org/10.17613/M6D50K

Green, Jonathon. 1990. "Rumania [sic]." The Encyclopedia of Censorship, 260-61. New York, NY: Facts on File.

Jacobs, Nicholas. 1998. “The Old English ‘Book-moth' Riddle Reconsidered.” Notes and Queries, 35(3): 29092. DOI: https://doi.org/10.1093/nq/35-3-290b

Komaromi, Ann. 2015. Project for the Study of Dissidence and Samizdat. https://samizdatcollections.library. utoronto.ca.

Komaromi, Ann. 2017. "Samizdat." WDW235: Introduction to Digital Humanities. Class lecture at the University of Toronto, Toronto, ON, September 28, 2017.

Krapp, George Philip, and Elliott Van Kirk Dobbie. 1936. The Exeter Book. New York: Columbia University Press.

Liu, Alan. 2007. "Imagining the New Media Encounter." In: A Companion to Digital Literary Studies, Ray Siemens, and Susan Schreiber (eds.), 3-25. Malden, MA: Blackwell.

Liu, Alan. 2014. "English 197: Close Reading and Distant Reading in Literary Studies." Syllabus. http:// english197w2014.pbworks.com/w/page/71971382/FrontPage Accessed May 30, 2018.

Liu, Alan. 2017. "Hacking Literary Interpretation." Syllabus. http://english197s2015.pbworks.com/w/ page/93127947/FrontPage Accessed May 30, 2018.

Mapes, Kristen. 2017. "Teaching Introduction to Digital Humanities Courses Beyond the Canon." Presented at Innovations in Digital Humanities Pedagogy: Local, National, and International Training. University of McGill, Montreal, August 8, 2017. https://www.kristenmapes.com/dhpedagogyconf2017/. Archived at: https://perma.cc/C3WV-FN47.

McClurken, Jeffrey. 2011. "Teaching and Learning with Omeka: Discomfort, Play, and Creating Public, Online, Digital Collections." In: Learning Through Digital Media Experiments in Technology and Pedagogy, R. Trebor Scholz (ed.), 137-49. New York: The Institute for Distributed Creativity.

McGann, Jerome J. 2001. Radiant Textuality: Literature after the World Wide Web. New York: Palgrave. DOI: https://doi.org/10.1007/978-1-137-10738-1

National Centre for Truth and Reconciliation. n.d. "About the National Centre for Truth and Reconciliation." Accessed May 30, 2018. http://nctr.ca/about-new.php.

Nowviskie, Bethany. 2014. "Neatline \& Visualization as Interpretation." Bethany Nowviskie (blog), November 2, 2014. http://nowviskie.org/2014/neatline-and-visualization-as-interpretation/. Archived at: https:// perma.cc/T9B6-NNYN Accessed May 30, 2018.

Nowviskie, Bethany. 2015. "Digital Humanities in the Anthropocene." Digital Scholarship in the Humanities, 30(suppl_1): i4-i15. DOI: https://doi.org/10.1093/llc/fqv015

Nowviskie, Bethany. 2016. "Everywhere, Everywhen." Presented at Insuetude. Columbia University, April 28, 2016. Accessed February 21, 2018. http://nowviskie.org/2016/everywhere-every-when/. Archived at: https://perma.cc/GT93-73KH.

Nowviskie, Bethany. 2017. "5 Spectra for Speculative Knowledge Design.” Bethany Nowviskie (blog), April 22, 2017. Accessed February 21, 2018. http://nowviskie.org/2017/5-spectra/\#more-3024. Archived at: https://perma.cc/K7EY-CW58.

O'Brien O'Keeffe, Katherine. 1994. "Editing and the Material Text." The Editing of Old English: Papers from the 1990 Manchester Conference, D. G. Scragg, and Paul E. Szarmach (eds.), 147-54. Cambridge: D. S. Brewer.

Posner, Miriam. 2015a. "Humanities Data: A Necessary Contradiction." Presented at the Harvard Purdue Data Management Symposium. Cambridge, MA, June 17, 2015. Accessed February 21, 2018. http:// 
miriamposner.com/blog/humanities-data-a-necessary-contradiction/. Archived at: https://perma.cc/ L5DF-6QV7.

Posner, Miriam. 2015b. "Introduction to Digital Humanities." Syllabus. Accessed February 21, 2018. http:// miriamposner.com/dh 101f15.

Posner, Miriam. 2017. "Annotated Bibliography Guidelines." Introduction to Digital Humanities. Syllabus. Accessed May 20, 2018. http://miriamposner.com/classes/dh101f17/assignments/final-project/ milestones/annotated-bibliography-guidelines/. Archived at: https://perma.cc/9PCN-YV4B.

Renoir, Alain. 1988. A Key to Old Poems: The Oral-Formulaic Approach to the Interpretation of West-Germanic Verse. University Park: Pennsylvania State University Press.

Schlitz, Stephanie A., and Garrick S. Bodine. 2012. "The Martha Berry Digital Archive Project: A Case Study in Experimental pEDagogy." Code4Lib, 17(June 1): n.p. http://journal.code4lib.org/articles/6823. Archived at: https://perma.cc/YG5A-5FKD.

Selisker, Scott. 2016. "Digital Humanities Knowledge: Reflections on the Introductory Graduate Syllabus." In: Debates in the Digital Humanities, Matthew K. Gold, and Lauren F. Klein (eds.). Minneapolis: University of Minnesota Press. https://www.jstor.org/stable/10.5749/j.ctt1cn6thb.

Spiro, Lisa. 2010. "Digital Humanities Education." Zotero Group Library. Registered September 11, 2010; accessed May 30, 2018. https://www.zotero.org/groups/25016/digital_humanities_education.

Swafford, Joanna. 2016. "Read, Play, Build: Teaching Sherlock Holmes through Digital Humanities." In: Digital Humanities 2016: Conference Abstracts, 371-72. Jagiellonian University \& Pedagogical University: Kraków. http://dh2016.adho.org/abstracts/431. Archived at: https://perma.cc/PF86-4SWM. Syllabus: https://hawksites.newpaltz.edu/dhm293/.

Tansey, Eira. 2017. "When the Unbearable Becomes Inevitable: Archives and Climate Change." Presented at Fierce Urgencies: The Social Responsibility of Collecting and Protecting Data. Beinecke Speaker Series at Yale University, New Haven, CT, May 16, 2017. http://eiratansey.com/2017/05/16/fierce-urgencies-2017/. Archived at: https://perma.cc/4D5J-7R5N.

Trettien, Whitney. 2017. "How We Read (Freshman Year Seminar syllabus)." Syllabus. DOI: https://doi. org/10.17613/M6CW3N

Truth and Reconciliation Commission of Canada. 2015. The Survivors Speak: A Report of the Truth and Reconciliation Commission of Canada. Accessed February 21, 2018. http://www.trc.ca/websites/ trcinstitution/File/2015/Findings/Survivors_Speak_2015_05_30_web_o.pdf.

University of Toronto Libraries. 2018. "Research Data Management" (policies and best practices). https:// onesearch.library.utoronto.ca/researchdata/ Accessed May 30, 2018.

University of Toronto Libraries. 2018. "University of Toronto Libraries Undergraduate Research Prize." https://onesearch.library.utoronto.ca/undergrad-research-prize/criteria/ Accessed May 30, 2018. Archived at: https://perma.cc/8SQ3-VGZ8.

Zumthor, Paul. 1972. Essai de poétique médiévale, Collection Poétique. Paris: Éditions du Seuil.

How to cite this article: Bolintineanu, Alexandra, and Jaya Thirugnanasampanthan. 2018. The Typewriter Under the Bed: Introducing Digital Humanities through Banned Books and Endangered Knowledge. KULA: Knowledge creation, dissemination, and preservation studies 2(1): 22. DOI: https://doi.org/10.5334/kula.30

Submitted: 02 March $2018 \quad$ Accepted: 01 August $2018 \quad$ Published: 29 November 2018

Copyright: (c) 2018 The Author(s). This is an open-access article distributed under the terms of the Creative Commons Attribution 4.0 International License (CC-BY 4.0), which permits unrestricted use, distribution, and reproduction in any medium, provided the original author and source are credited. See http://creativecommons.org/ licenses/by/4.0/.

$\mathrm{Ju}[\quad$ KULA: Knowledge creation, dissemination, and preservation studies is a peer-reviewed open access journal published by Ubiquity Press. 